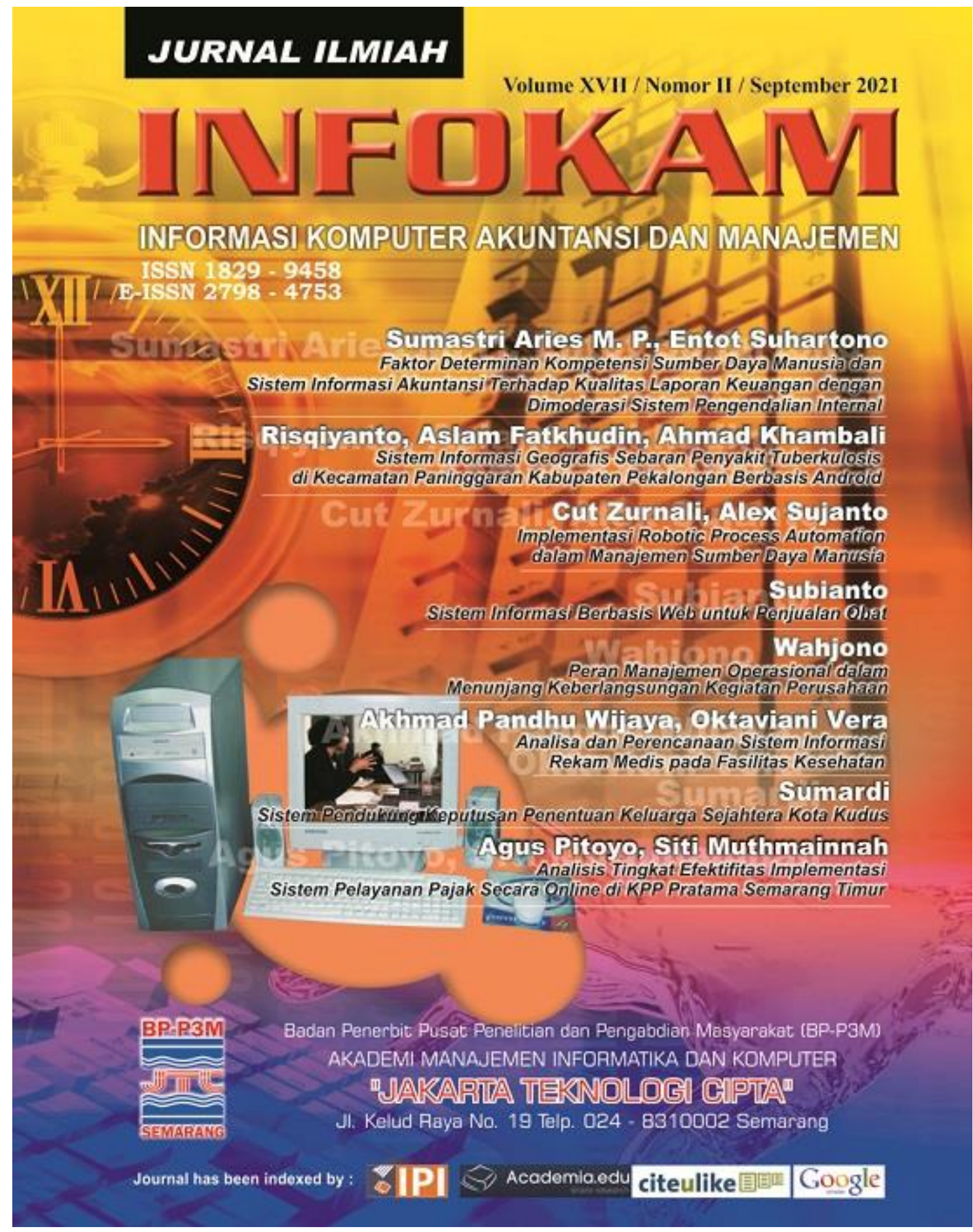


INFORMASI KOMPUTER AKUNTANSI DAN MANAJEMEN

ISSN 1829 - 9458

E-ISSN 2798 - 4753

SK DIREKTUR AMIK "JTC" SEMARANG

NO. 6305/AMIKJTC/D/IX/2020

Penasehat : Dr. Alex Sujanto, SE, S.Pd, MM. (Direktur)

Pengarah : Kristiawan Nugroho, M.Kom (Pudir I)

Muhamad Danuri, M.Kom (Pudir III)

Penanggung Jawab : Sumardi, S.Kom, M.Kom (Ka Progdi KA)

Subianto, S.Kom, M.Kom (Ka.Progdi MI)

Ketua Dewan Redaksi

Wahjono, SE, M.Si (Ketua Editor)

Sekretaris Editor

Anton Sujarwo, M.Si

Bendahara

Agus Pitoyo, M.Si

Anggota Dewan Editor

Subianto, M.Kom

Sumardi, M.Kom

Dr. Heru Sulistyo, SE, MSI ( STIE Dharmaputra Semarang)

Agus Prasetyo Utomo, MM., M.Kom (Univ. Stikubank Semarang)

Ira Setiawati, SE, M.Si (Univ. PGRI Semarang)

Eko Riyanto, S.Pd, M.Kom (STMIK Himsya Semarang)

Editor Teknis Dan Pelaksana

Sugeng Murdowo, S.T, S.Kom, M.Kom

Dr. Alex Sujanto, SE, S.Pd, MM

Mitra Bestari Peer Reviewer

Komputer

Daniel Alfa Puryanto, M.Kom (STMIK AKI Pati)

Aslam Fathkudin, M.Kom (Univ. Muh. Pekajangan Pekalongan)

Entot Suhartono, M.Kom (Univ. Dian Nuswantoro)

Fata Nida'ul Khasanah, M.Eng (Univ. Bhayangkara Jakarta Raya)

Noor Azizah, S.Kom, M.Kom (Univ. Islam Nahdatul Ulama Jepara)

\section{Akuntansi}

Dr. Heru Sulistiyo, M.Si, Akt (STIE Dharmaputra Semarang)

Arini Novandalina, M.Si (STIE Semarang)

Manajemen

Prof. Dr. Amron, SE. MM (Univ. Dian Nuswantoro Semarang)

Entot Suhartono, M. Kom (Univ. Dian Nuswantoro Semarang)

\section{Section Editor}

Subianto, S.Kom, M.Kom

Jurnal Ilmiah INFOKAM terbit minimal setiap 6 bulan sekali $(2 \mathrm{X}$ dalam setahun, bulan Maret \& September ) oleh AMIK "JTC" Semarang dengan maksud sebagai media informasi tentang Komputer, Akuntansi dan Manajemen bagi Sivitas Akademika pada khususnya dan masyarakat pada umumnya.

Alamat Redaksi / Penerbit :

Badan Penerbit Pusat Penelitian dan Pengabdian Masyarakat (BP-P3M)

AKADEMI MANAJEMEN INFORMATIKA DAN KOMPUTER

"JAKARTA TEKNOLOGI CIPTA"

Jl. Kelud Raya No. 19 Telp. 024 - 8310002 Semarang www.amikjtc.com/jurnal, email : infokam.amikjtc@gmail.com 


\section{INFORMASI KOMPUTER AKUNTANSI DAN MANAJEMEN \\ ISSN 1829 - 9458 \\ E-ISSN 2798 - 4753}

\section{DAFTAR ISI}

Faktor Determinan Kompetensi Sumber Daya Manusia dan Sistem Informasi Akuntansi Terhadap Kualitas Laporan Keuangan dengan Dimoderasi Sistem Pengendalian Internal

Sumastri Aries M. P., Entot Suhartono

Sistem Informasi Geografis Sebaran Penyakit Tuberkulosis di Kecamatan Paninggaran Kabupaten Pekalongan Berbasis Android

Risqiyanto, Aslam Fatkhudin, Ahmad Khambali

Implementasi Robotic Process Automation Dalam Manajemen Sumber Daya Manusia

Cut Zurnali, Alex Sujanto

Sistem Informasi Berbasis Web untuk Penjualan Obat

Subianto

Peran Manajemen Operasional dalam Menunjang Keberlangsungan Kegiatan Perusahaan

Wahjono

Analisa dan Perencanaan Sistem Informasi Rekam Medis pada Fasilitas Kesehatan

Akhmad Pandhu Wijaya, Oktaviani Vera

Sistem Pendukung Keputusan Penentuan Keluarga Sejahtera Kota Kudus Sumardi

Analisis Tingkat Efektifitas Implementasi Sistem Pelayanan Pajak Secara Online di KPP Pratama Semarang Timur Agus Pitoyo, Siti Muthmainnah 


\title{
Analisa dan Perencanaan Sistem Informasi Rekam Medis pada Fasilitas Kesehatan
}

\author{
Akhmad Pandhu Wijaya \\ (Manajemen Informatika AMIK Jakarta Teknologi Cipta Semarang) \\ Email : pandhujobs@gmail.com \\ Oktaviani Vera \\ (Keperawatan STIKES Pertamina Bina Medika Jakarta)
}

\begin{abstract}
Abstrak
Rumah Sakit mempunyai fungsi dan tujuan sarana pelayanan kesehatan yang menyelenggarakan kegiatan pelayanan berupa pelayanan rawat jalan, pelayanan rawat inap, pelayanan gawat darurat, pelayanan rujukan yang mencakup pelayanan rekam medis dan penunjang medis serta dimanfaatkan untuk pendidikan, pelatihan, dan penelitian bagi para tenaga kesehatan. Rekam medis merupakan bukti tertulis mengenai proses pelayanan yang diberikan kepada pasien oleh dokter dan tenaga kesehatan lainnya, yang mana dengan adanya bukti tertulis tersebut maka rekam medis yang diberikan dapat dipertanggung jawabkan, dengan tujuan sebagai penunjang tertib administrasi dalam upaya peningkatan pelayanan kesehatan rekam medis. Rumah Sakit yang sudah menerapkan sistem informasi rekam medis dalam proses pelayanan pendataan pasiennya, tetapi masih belum terintegrasi dalam hal pendataan pasien dari mulai pendaftaran sampai kebagian rekam medis. Metodologi yang digunakan dalam perancangan sistem informasi ini menggunakan Model UML (Unified Modelling Language). Metodologi ini dapat digunakan untuk menganalisa dan merancang sistem informasi rekam medis, sehingga hasil dari sistem informasi rekam medis ini dapat membantu mengatasi masalah-masalah yang ada dan tidak ada lagi pencatatan data berulang kali dan bila data diperlukan dapat segera langsung dilihat. Kata Kunci : rumah Rumah Sakit, Sistem Informasi, Rekam Medis, UML.
\end{abstract}

\begin{abstract}
Abstrack
A hospital has the function and purpose of a health service facility that provides service activities in the form of outpatient services, inpatient services, emergency services, referral services which include medical record services and medical support and are used for education, training and research for health workers. The medical record is written evidence regarding the service process provided to patients by doctors and other health workers, where with this written evidence the medical record provided can be accounted for, with the aim of supporting orderly administration in efforts to improve medical record health services. Hospitals that have implemented a medical record information system in their patient data collection services process, but are still not integrated in terms of patient data collection from registration to receiving medical records. The methodology used in the design of this information system uses the UML (Unified Modeling Language) Model. This methodology can be used to analyze and design a medical record information system, so that the results of this medical record information system can help overcome existing problems and no longer record data repeatedly and when data is needed immediately seen.

Keywords : Hospital, Information System, Medical Records, UML
\end{abstract}

\section{Pendahuluan}

Seiring dengan perkembangan ilmu pengetahuan dan teknologi saat ini, keberadaan komputer sangat-sangat dibutuhkan, baik itu di perusahaan-perusahaan, Instansi Pemerintah, instansi swasta, perdagangan dan jasa maupun rumah sakit, komputer banyak digunakan dalam banyak hal, baik sebagai pelaporan, proses pengolahan data maupun untuk keperluan lainnya. tanpa adanya komputer maka pekerjaan yang dikerjakan akan memakan waktu yang sangat lama, banyaknya tenaga yang dibutuhkan. serta hasilnya tidak optimal atau kurang relevan. Komputerisasi Data Rekam medis merupakan sebuah program aplikasi rumah sakit yang dibuat 
untuk mempermudah bagian bagian rekam medis untuk mengolah dan menginputkan data serta dapat dimodifikasi data tersebut secara cepat dan tepat sehingga dapat digunakan kembali untuk melihat laporan pasien baik secara keseluruhan, kelompok dan keperluan lainnya. Pengolahan data rekam medis menggunakan komputer di rumah sakit saat ini sangat dirasakan keberadaannya, sehingga pekerjaan dapat diselesaikan dengan cepat, tepat dan efisien. Beberapa penelitian sebelumnya menyatakan bahwa kekurangan pada sistem pengelolaan dan penyusunan data perawat masih menjadi perhatian khusus. (Mubarok et al., 2016)

\section{Landasan Teori}

\section{a. Sistem}

Suatu sistem berdasarkan penekanan pada elemem atau komponen adalah kumpulan dari elemen - elemen yang saling berinteraksi untuk mencapai suatu tujuan dan sasaran tertentu dari suatu organisasi (Ninla Elmawati Falabiba et al., 2014). Dari beberapa definisi tersebut, maka dapat disimpulkan pengertian sistem adalah sebagai berikut :

1) Sistem adalah suatu jaringan kerja dari prosedur-prosedur yang saling berhubungan, berkumpul bersama-sama untuk melakukan suatu kegiatan atau untuk menyelesaikan suatu sasaran tertentu.

2) Sistem adalah kumpulan elemen-elemen yang saling berhubungan dan bertanggung jawab memproses masukan sehingga menghasilkan keluaran.

3) Sistem adalah kumpulan (gabungan objek atau ide) yang saling terpadu untuk mencapai tujuan tertentu.

4) Sistem adalah sesuatu yang mempunyai tujuan dan sasaran sebagai hasil akhir.

5) Sistem adalah sebuah tatanan (keterpaduan) yang terdiri atas sejumlah komponen fungsional yang saling berhubungan dan secara bersama-sama bertujuan untuk memenuhi suatu proses ataupun pekerjaan tertentu.

\section{b. Sistem Informasi}

Sistem informasi adalah suatu sistem didalam suatu organisasi yang mempertemukan kebutuhan, pengolahan transaksi harian, pendukung operasi, bersifat manajerial dan kegiatan strategi dari suatu organisasi serta penyediaan laporan-laporan yang diperlukan bagi pihak luar tertentu.

Sistem informasi adalah seperangkat tata cara metodologi organisasi perangkat lunak, dan perangkat keras yang dibutuhkan untuk memasukkan dan mengambil kembali data yang dibutuhkan untuk menjalankan dan mengelola organisasi. Sistem informasi rumah sakit adalah suatu tatanan yang berurusan dengan pengumpulan data, pengelolaan data, penyajian informasi, analisa dan penyimpulan informasi serta penyampaian informasi yang dibutuhkan untuk kegiatan rumah sakit. Tugas utama dari pembangunan sebuah sistem informasi keperawatan adalah mendukung proses perawatan pasien, manajemen lingkungan, komunikasi serta kerja sama dengan profesi kesehatan lainnya. (Syam \& Sukihananto, 2019)

\section{c. Rekam Medis}

Rekam medis adalah berkas yang berisikan catatan dan dokumen tentang identitas pasien pemeriksaan, pengobatan, tindakan dan pelayanan lain kepada pasien pada sarana pelayanan kesehatan. Rekam medis adalah berkas yang berisikan catatan dandokumen tentang identitas pasien, pemeriksaan, pengobatan, tindakan dan pelayanan lain yang telah diberikan kepada pasien.

Berdasarkan beberapa pengertian yang dikemukakan dapat disimpulkan bahwa yang dimaksud rekam medis adalah berkas yang berisi catatan dan dokumen tentang identitas pasien, pemeriksaan, pengobatan, tindakan dan pelayanan lain yang telah diberikan kepada pasien pada sarana pelayanan kesehatan.

Rekam medis memeiliki isi yang sering digunakan berupa :

1) Catatan, yang memiliki uraian terkait identitas seorang pasien, pemeriksaan yang dilakukan kepada pasien, diagnosa yang diberikan, riwayat pengobatan, serta pelayanan dan tindakan yang dilakukan oleh dokter maupun tenaga kesehatan lainnya.

2) Dokumen, berupa kelengkapan dari catatan yang diuraikan pada nomor 1 seperti foto rontgen, hasil pengecekan laboratorium, serta keterangan lain sesuai dengan kompetensi keilmuan. (Kedokteran, 2006) 
Peraturan Mentri Kesehatan Republik Indonesia No. 169 /MENKES/ PER/III/2008 menjelaskan bahwa rekam medis memiliki manfaat sebagai berikut: (Kamal, 2017)

1) Pengobatan

Rekam medis bermanfaat sebagai dasar dan petunjuk untuk merencanakan dan menganalisis penyakit serta merencanakan pengobatan, perawatan dan tindakan medis yang harus diberikan kepada pasien.

2) Peningkatan Kualitas Pelayanan

Rekam Medis bagi penyelenggaraan praktik kedokteran dengan jelas dan lengkap akan meningkatkan kualitas pelayanan untuk melindungi tenaga medis dan untuk pencapaian kesehatan masyarakat yang optimal.

3) Pendidikan dan Penelitian

Rekam medis yang merupakan informasi perkembangan kronologis penyakit, pelayanan medis, pengobatan dan tindakan medis, bermanfaat untuk bahan informasi bagi perkembangan pengajaran dan penelitian dibidang profesi kedokteran dan kedokteran gigi.

4) Pembiayaan

Berkas rekam medis dapat dijadikan petunjuk dan bahan untuk menetapkan pembiayaan dalam pelayanan kesehatan pada sarana kesehatan. Catatan tersebut dapat dipakai sebagai bukti pembiayaan kepada pasien.

5) Statistik Kesehatan

Rekam medis dapat digunakan sebagai bahan statistik kesehatan, khususnya untuk mempelajari perkembangan kesehatan masyarakat dan untuk menentukan jumlah penderita pada penyakit penyakit tertentu.

6) Pembuktian Masalah Hukum, Disiplin dan Etik

Rekam medis merupakan alat bukti tertulis utama, sehingga bermanfaat dalam penyelesaian masalah hukum, disiplin dan etik.

\section{d. Sistem Penomoran Rekam Medis}

Penomoran rekam medis terdiri dari 6 (enam) digit angka yang terdiri dari 2 (dua) digit Angka Awal, 2 (dua) digit Angka Tengah, 2 (dua) digit Angka Akhir. Enam angka tersebut dimulai dari 00.00.01 s/d 99.99.99. Ada 3 (tiga) sistem penomoran pasien (administration numbering system) yaitu:

1) Pemberian Nomor Secara Seri (Serial Numbering System)

Sistem penomoran ini merupakan sistem penomoran dimana setiap pasien yang berkunjung di sarana pelayanan kesehatan akan mendapatkan nomor baru.

Keuntungan:

a) Petugas rekam medis lebih mudah dalam pemberian nomor kepada pasien

b) Petugas rekam medis lebih cepat dalam memberikan pelayanan kepada pasien Kerugian:

a) Membutuhkan waktu lama dalam melakukan pencarian terhadap dokumen rekam medis lama, karena 1 (satu) pasien dapat memiliki lebih dari 1 (satu) nomor rekam medis

b) Informasi pelayanan klinik menjadi tidak berkesinambungan

2) Pemberian Nomor Secara Unit (Unit Numbering System)

Merupakan suatu sistem penomoran dimana sistem ini memberikan satu nomor kepada pasien rawat jalan, rawat inap dan gawat darurat. Setiap pasien yang berkunjung akan mendapatkan nomor pada saat pertama kali kunjungan dan dapat digunakan kembali untuk seterusnya. Sistem penomoran ini dibagi menjadi 2 (dua) yaitu:

a) Social security numbering, artinya penomoran ini berhubungan dengan lingkungannya dan hanya di Amerika Serikat dan efektif pada veteran administration hospital. Keuntungannya adalah dapat dibedakan dengan pasien yang lainnya.

b) Family numbering, artinya penomoran ini berhubungan dengan keluarga (satu nomor untuk satu keluarga). Biasanya sistem penomoran ini diterapkan di Puskesmas. Terdiri dari sepasang digit tambahan yang ditempatkan pada setiap keluarga. Keuntungan dari menggunakan sistem ini adalah informasi klinis dapat terkumpul dalam satu folder dan hanya mempunyai 1 (satu) kartu berobat yang dapat digunakan untuk seluruh keluarga. 
3) Pemberian Nomor Secara Seri-Unit (Serial-Unit Numbering System)

Penomoran ini dilakukan dengan cara menggunakan gabungan antara nomor seri dan nomor unit. Setiap pasien yang datang berkunjung diberikan nomor baru tetapi dokumen rekam medis terdahulu digabungkan dan disimpan jadi satu dibawah nomor baru.

Keuntungan menggunakan sistem penomoran ini adalah kemudahan dalam pencarian dokumen rekam medis. Kekurangannya adalah petugas rekam medis menjadi lebih sibuk setelah selesai pelayanan dan informasi yang diberikan kepada pasien tidak berkesinambungan.

\section{e. Kodifikasi warna rekam medis}

Kode warna rekam medis adalah salah satu petunjuk khusus yang tertera pada sampul berkas rekam medis yang biasanya ditempel pada 1 atau 2 digit terakhir nomor rekam medis yang terletak disebelah kanan sampul. Tujuan dari penggunaan kode warna ini antara lain:

1. Mengurangi kesalahan penyimpanan berkas rekam medis

2. Memudahkan pencarian berkas rekam medis apabila salah simpan

3. Mempercepat pengambilan dan penyimpanan berkas rekam medis pada rak penyimpanan.

Rumah sakit mengaplikasikan penomoran berkas rekam medis dengan sistem nomor langsung berdasarkan angka terakhir pada 1 (satu) digit angka index terakhir. Kodefikasi warna untuk setiap angka index rekam medis ditempel tepat dibawah angka index tersebut.

\section{f. Kebermanfaatan Rekam Medis}

1) Peningkatan Kualitas Pelayanan. Membuat Rekam Medis bagi penyelenggaraan praktik kedokteran dengan jelas dan lengkap akan meningkatkan kualitas pelayanan untuk melindungi tenaga medis dan untuk pencapaian kesehatan masyarakat yang optimal.

2) Pendidikan dan Penelitian. Rekam medis yang merupakan informasi perkembangan kronologis penyakit, pelayanan medis, pengobatan dan tindakan medis, bermanfaat untuk bahan informasi bagi perkembangan pengajaran dan penelitian di bidang profesi kedokteran dan kedokteran gigi.

3) Pembiayaan Berkas rekam medis dapat dijadikan petunjuk dan bahan untuk menetapkan pembiayaan dalam pelayanan kesehatan pada sarana kesehatan. Catatan tersebut dapat dipakai sebagai bukti pembiayaan kepada pasien

4) Statistik Kesehatan Rekam medis dapat digunakan sebagai bahan statistik kesehatan, khususnya untuk mempelajari perkembangan kesehatan masyarakat dan untuk menentukan jumlah penderita pada penyakit- penyakit tertentu

5) Pembuktian Masalah Hukum, Disiplin dan Etik Rekam medis merupakan alat bukti tertulis utama, sehingga bermanfaat dalam penyelesaian masalah hukum, disiplin dan etik.

\section{Penggunaan Database}

a. Kemudahan berbagi data

Dengan adanya database maka dapat dibagikan ke sesama pengguna menggunakan software atau perangkat lunak.

b. Menjaga Keamanan Data

Keaman akan informasi dan data terjamin dalam database, karena bisa menyisipkan suatu kode akses data-data tertentu agar tidak dapat diakses oleh orang lain

c. Kemudahan Akses Data

Karena semua data terorganisir, maka dengan mudah mendapatkan dan mengakses data di database.

\section{Sistem Informasi Keperawatan}

Hubungan dari kesemua poin yang telah dipaparkan adalah untuk mendukung kinerja profesi keperawatan, dengan fungsi tersebut maka segala administrasi pendukung fungsi keperawatan akan membantu perawat, manfaat aplikasi sistem informasi keperawatan antara lain :

a. Waktu yang lebih banyak dihabiskan dengan pasien dibanding dengan waktu di ruang 
perawat.

b. Mengurangi resiko kehilangan kertas dan mengurangi penggunaan kertas.

c. Dokumentasi keperawatan dapat dilakukan secara otomatis.

d. Standar perawatan dapat diprogram dengan seragam.

e. Meminimalisir biaya.

f. Pengukuran Kualitas.

\section{Metode Penelitian}

Penelitian Kepustakaan (Library Research), pada penelitian ini berguna untuk melengkapi perbendahaaraan teori, konsep dan metode metode ini data dikumpulkan dengan membaca literatur-literatur, baik itu dari buku-buku, jurnal-jurnal dan majalahmajalah serta dari internet yang berhubungan dengan pemograman komputer, khususnya dibagian rekam medis.

\section{a. Perancangan Sistem}

Analis proses ini untuk menggambarkan proses sistem informasi penyimpanan rekam medis rawat inap maka proses bisnis adalah sebagai berikut:

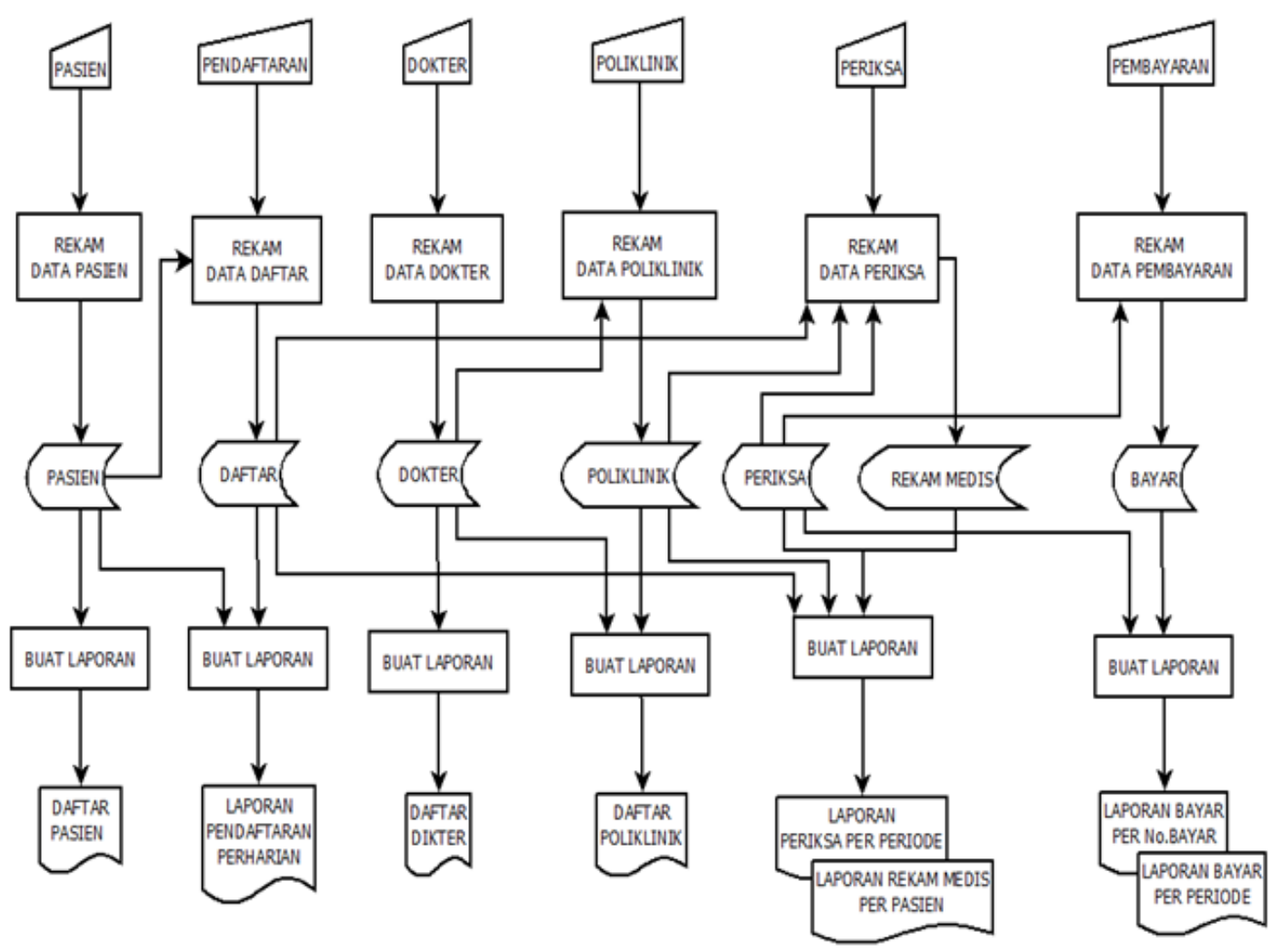

Gambar 1 Flowchart Sistem Informasi 
b. Alur Sistem
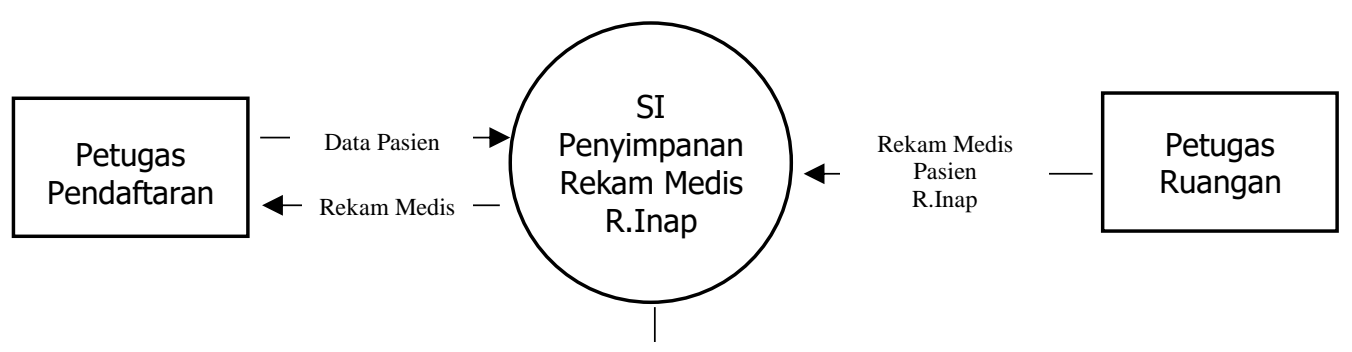

Rekapitulasi Eksepisi

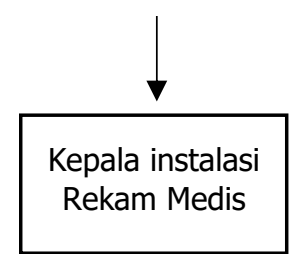

Gambar 2 Diagram sistem

\section{Desain dan Implemetasi Sistem}

a. Desain Halaman Utama

Setelah user login seperti pada Gambar 3, halaman utama atau beranda yang berisi konten statistik data jumlah pasien maupun dokter.

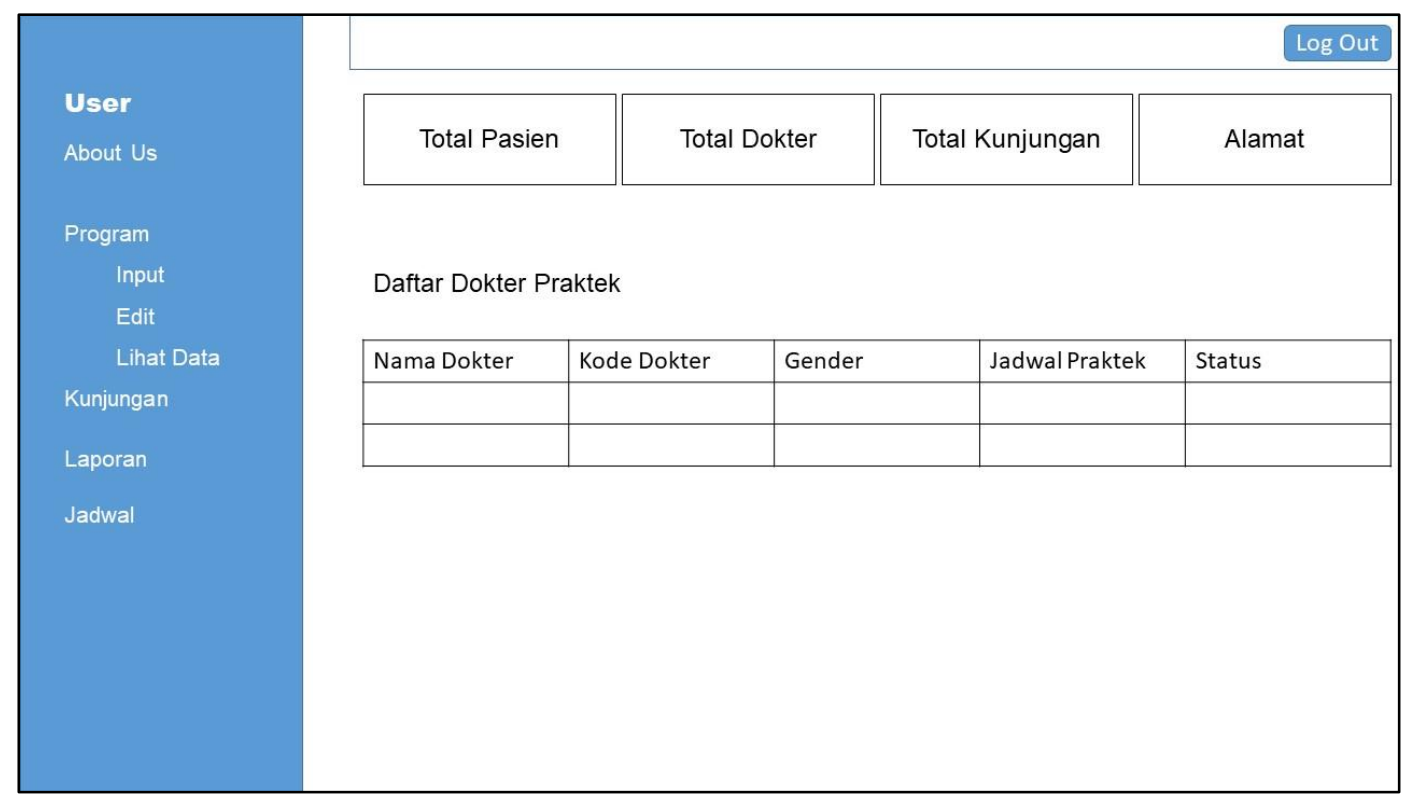

Gambar 3 Desain Input Data Pasien 


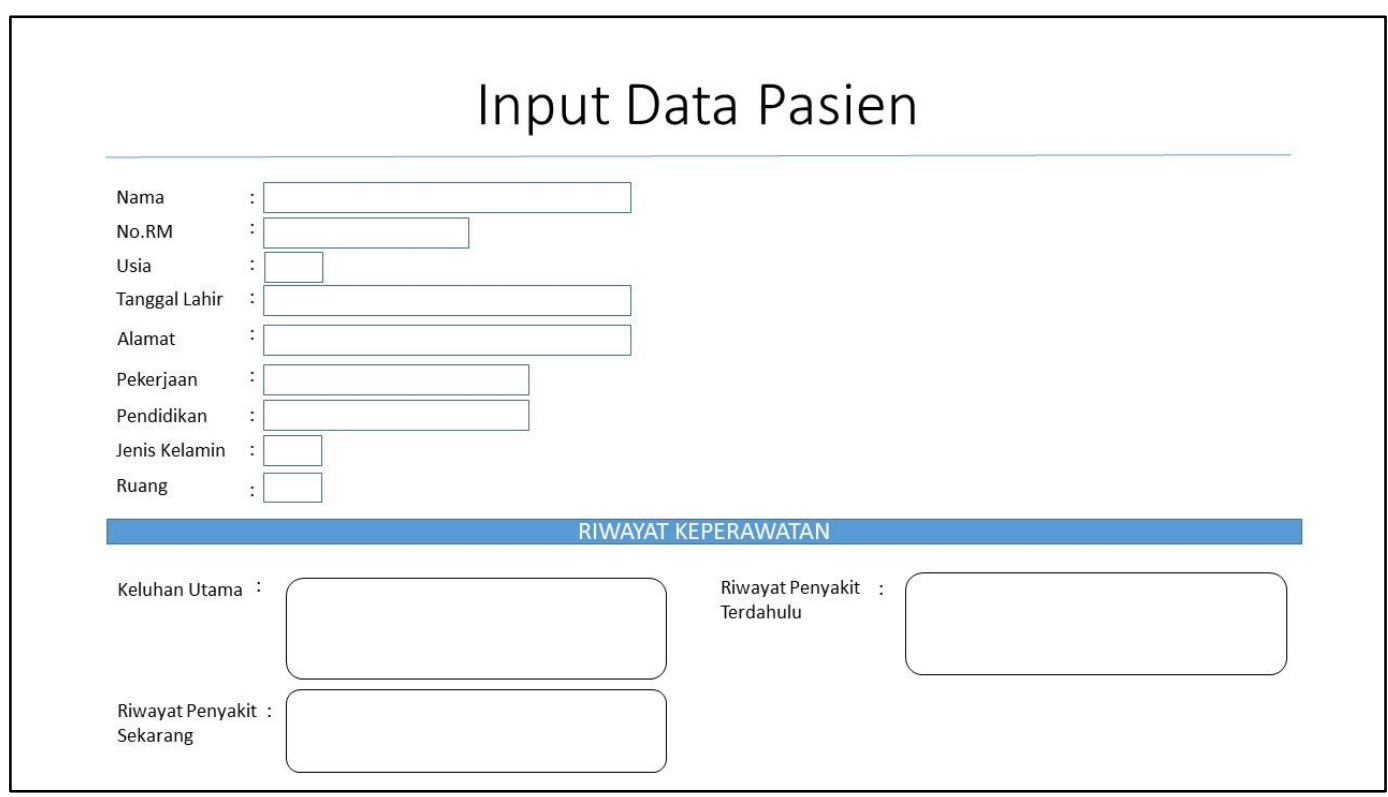

Gambar 4 Input Pasien

Desain Halaman Input Data Pasien Pada halaman input seperti ditunjukkan pada Gambar 4 hanya admin yang diperkenankan untuk melakukan input data pribadi pasien.

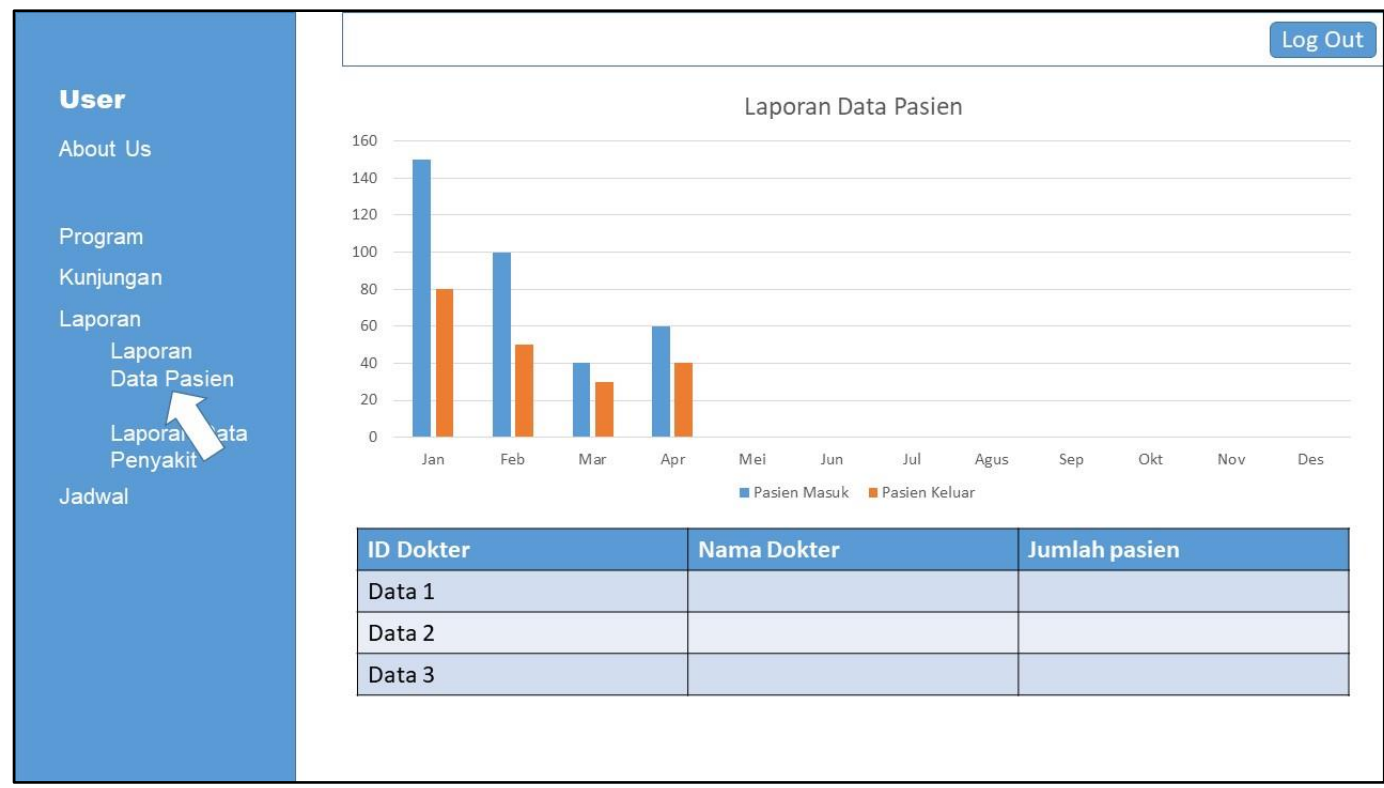

Gambar 5 Laporan Data pasien

Desain Halaman Laporan Data Pasien. Laporan data pasien berisi tentang jumlah data yang telah diolah sehingga dapat dianalisis pertumbuhan pasien setiap bulannya. Seperti ditunjukkan pada Gambar 5.

\section{Kesimpulan}

Sistem informasi adalah seperangkat tata cara metodologi organisasi perangkat lunak dan perangkat keras yang dibutuhkan untuk memasukkan dan mengambil kembali data yang dibutuhkan untuk menjalankan dan mengelola organisasi. Sistem informasi rumah sakit adalah suatu tatanan yang berurusan dengan pengumpulan data, pengelolaan data, penyajian informasi, analisa dan penyimpulan informasi serta penyampaian informasi yang dibutuhkan untuk kegiatan rumah sakit. 


\section{Daftar Pustaka}

Kamal, S. (2017). Pengolahan Data Rekam Medis Rumah Sakit Menggunakan Pemograman Visual Foxpro-9. In Majalah IImiah (Vol. 24, Issue 1, pp. 114-120).

Kedokteran, K. (2006). Ma n u a Ireka mmedis.

Mubarok, R., Mauluddin, S., Indonesia, U. K., \& Indonesia, U. K. (2016). Sistem Informasi Keperawatan Berbasis Web Pada Rumah Sakit Mata Bandung Eye Center Web Based Nursing Information System at Bandung Eye Hospital Eye Center. 1.

Ninla Elmawati Falabiba, Anggaran, W., Mayssara A. Abo Hassanin Supervised, A., Wiyono, B. ., Ninla Elmawati Falabiba, Zhang, Y. J., Li, Y., \& Chen, X. (2014). 済無No Title No Title No Title. Paper Knowledge. Toward a Media History of Documents, 5(2), 40-51.

Syam, Ahmad dah, \& Sukihananto. (2019). Manfaat dan Hambatan dalam Pelaksanaan Sistem Informasi Keperawatan. Jurnal Keperawatan Muhammadiyah, 3, 156-164. 